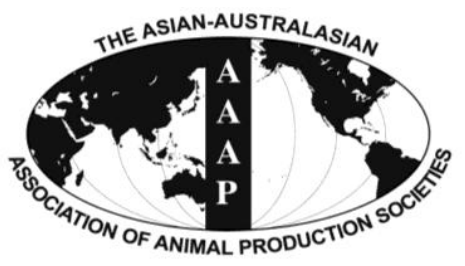

Asian Australas. J. Anim. Sci.

Vol. 26, No. 8 : 1181-1188 August 2013

http://dx.doi.org/10.5713/ajas.2013.13129

www.ajas.info

pISSN 101 1-2367 elSSN 1976-5517

\title{
The Effects of Enzyme Complex on Performance, Intestinal Health and Nutrient Digestibility of Weaned Pigs
}

\author{
J. Q. Yi, X. S. Piao, Z. C. Li, H. Y. Zhang, Y. Chen, Q. Y. Li, J. D. Liu, \\ Q. Zhang, Y. J. Ru' ${ }^{1}$, and B. Dong* \\ State Key Laboratory of Animal Nutrition, Ministry of Agriculture Feed Industry Centre, \\ China Agricultural University, Beijing 100193, China
}

\begin{abstract}
Two experiments were conducted to evaluate the effect of supplementing a corn-soybean meal-based diet with an enzyme complex containing amylase, protease and xylanase on the performance, intestinal health, apparent ileal digestibility of amino acids and nutrient digestibility of weaned pigs. In Exp. 1, 108 piglets weaned at $28 \mathrm{~d}$ of age were fed one of three diets containing 0 (control), 100, or $150 \mathrm{ppm}$ enzyme complex for $4 \mathrm{wks}$, based on a two-phase feeding program namely 1 to $7 \mathrm{~d}$ (phase 1 ) and 8 to $28 \mathrm{~d}$ (phase 2). At the end of the experiment, six pigs from the control group and the group supplemented with 150 ppm enzyme complex were chosen to collect digesta samples from intestine to measure viscosity and $\mathrm{pH}$ in the stomach, ileum, and cecum, as well as volatile fatty acid concentrations and composition of the microflora in the cecum and colon. There were linear increases $(\mathrm{p}<0.01)$ in weight gain, gain: feed ratio and digestibility of gross energy with the increasing dose rate of enzyme supplementation during the whole experiment. Supplementation with enzyme complex increased the digesta viscosity in the stomach $(p<0.05)$ and significantly increased $(p<0.01)$ the concentrations of acetic, propionic and butyric acid in the cecum and colon. Enzyme supplementation also significantly increased the population of Lactobacilli $(\mathrm{p}<0.01)$ in the cecum and decreased the population of E. coli $(\mathrm{p}<0.05)$ in the colon. In Exp. 2, six crossbred barrows (initial body weight: $18.26 \pm 1.21 \mathrm{~kg}$ ), fitted with a simple T-cannula at the distal ileum, were assigned to three dietary treatments according to a replicated $3 \times 3$ Latin Square design. The experimental diets were the same as the diets used in phase 2 in Exp. 1 . Apparent ileal digestibility of isoleucine $(\mathrm{p}<0.01)$, valine $(\mathrm{p}<0.05)$ and aspartic acid $(\mathrm{p}<0.05)$ linearly increased with the increasing dose rate of enzyme supplementation. In conclusion, supplementation of the diet with an enzyme complex containing amylase, protease and xylanase improved piglet performance. This is likely a result of improvement in nutrient digestibility, volatile fatty acid concentrations and bacteria ratio in the large intestine. (Key Words: Enzyme Complex, Weaned Pigs, Performance, Intestinal Health, Apparent Ileal Digestibility)
\end{abstract}

\section{INTRODUCTION}

Enzymes have been used in livestock production for more than 20 yrs, especially in diet containing cereals with high levels of soluble non-starch polysaccharides (NSP) such as wheat, oats, barley and rye (Yin et al., 2000a, 2000b, 2001c; Yu et al., 2007). In recent years, however, enzymes have also been accepted by the industry for corn-based diets in both poultry and pigs (Fang et al., 2007; Olukosi et al., 2007; Francesch and Geraert, 2009; Willamil et al., 2012). Corn contains $0.9 \%$ soluble and $6 \%$ insoluble NSPs (contained approximately $42 \mathrm{~g} / \mathrm{kg}$ xylan), while soybean

\footnotetext{
* Corresponding Author: B. Dong. Tel: +86-62733588, Fax: +8662733688, E-mail: dongb@mafic.ac.cn

${ }^{1}$ Danisco Animal Nutrition, Singapore, 117525, Singapore.

Submitted Mar. 1, 2013; Accepted Apr. 8, 2013; Revised Jun. 4, 2013
}

contains $6 \%$ soluble and 18 to $21 \%$ insoluble NSPs (contained approximately $17 \mathrm{~g} / \mathrm{kg}$ xylan) (Bach Knudsen, 1997). The NSPs in corn mainly consist of insoluble arabinoxylans (Summers, 2001). Fang et al. (2007) reported that the supplementation of xylanase-based enzymes in corn-soybean based-diet improved the digestibility of energy and NDF and also improved average daily gain of growing pigs. This may indicate that corn-soybean baseddiet can provide the substrate for xylanase to work on.

Although the use of NSP-degrading carbohydrases has been widely and successfully used in poultry fed NSP-rich diets (Francesch and Geraert, 2009), the results are not as clear in pig (Mavromichalis et al., 2000; Cadogan et al., 2003; Barrera et al., 2004; Woyengo et al., 2008). The possible causes of the differences of performance in these studies could be the differences in cereal grain types and 
quality, animal age, and the bioefficacy of enzyme used. Therefore, the specific objective of these experiments was to evaluate the effects of supplementation with an enzyme complex containing amylase, protease and xylanase on performance, nutrient digestibility and the intestinal health of weaned pigs.

\section{MATERIALS AND METHODS}

All procedures used in these experiments were approved by the China Agricultural University Institutional Animal Care and Use Committee (Beijing, China).

\section{Diets and enzyme complex preparation}

The enzyme complex used in this study contained amylase, protease and xylanase; it was supplied by Danisco Animal Nutrition, UK. The pure enzyme product provided $2,000 \mathrm{U} / \mathrm{g}$ of amylase, 40,000 U/g of protease and 20,000 $\mathrm{U} / \mathrm{g}$ xylanase. One unit of xylanase is defined as the amount of enzyme which liberates $0.5 \mu \mathrm{mol}$ of reducing sugar (expressed as xylose equivalents) from a cross-linked oat spelt xylan substrate in one minute; one unit of protease is defined as the amount of enzyme which liberates $1 \mu \mathrm{mol}$ of phenolic compound (tyrosine equivalents) from a casein substrate per minute; one unit of protease is defined as the amount of enzyme which liberates $1 \mu$ mol of glucosidic linkages from a water insoluble cross-linked starch polymer substrate per minute.

In Exp. 1, all diets were pelleted $(1.5 \mathrm{~mm})$ at $70^{\circ} \mathrm{C}$. They were formulated to contain similar levels of nutrients and to meet or exceed the nutrient requirements for piglets (NRC, 1998). The residual enzyme activity of amylase, protease and xylanase after pelleting were 152, 3,832 and 2,107 U/kg for phase 1 and 242, 5,773 and 3,150 U/kg for phase 2. The ingredient composition and the analyzed nutrient content for phase 1 ( 1 to $7 \mathrm{~d}$ ) and phase 2 ( 8 to 28 d) are shown in Table 1. Diets used in Exp. 2 were the same as the diets used in phase 2 in Exp. 1.

\section{Experimental design}

Exp. 1. Growth performance, intestinal health and nutrient digestibility: In Exp. 1, a total of 108 crossbred piglets (Duroc $\times$ Landrace $\times$ Large White) weighing $7.51 \pm 1.10$ $\mathrm{kg}$ were used in a 28-d experiment. The three treatments consisted of a corn-soybean meal-based control diet and two experimental diets. The two experimental diets were the control diet supplemented with 100 or 150 ppm enzyme complex. Chromic oxide was included at $0.25 \%$ as an indigestible index for the determination of nutrient digestibility. The pigs were allocated to one of the three dietary treatments on the basis of weight and gender in a randomized complete block design with six replicates per treatment and six pigs per pen.
Table 1. Diet composition and nutrients levels of experimental diets fed to determine the effects of enzyme supplementation

\begin{tabular}{|c|c|c|}
\hline \multirow{2}{*}{ Ingredient $(\%)$} & \multicolumn{2}{|c|}{ Basal diet } \\
\hline & Phase 1 & Phase 2 \\
\hline$\overline{\text { Corn }}$ & 51.84 & 57.71 \\
\hline Soybean meal & 12.16 & 25.23 \\
\hline Extruded full fat soybean meal & 10.00 & 8.00 \\
\hline Fish meal & 2.00 & - \\
\hline Whey powder & 12.00 & 5.00 \\
\hline Sugar & 1.00 & - \\
\hline Dried porcine soluble & 3.00 & - \\
\hline Spray-dried plasma protein & 3.60 & - \\
\hline Soy oil & 0.66 & 0.74 \\
\hline Dicalcium phosphate & 1.14 & 1.20 \\
\hline Limestone & 0.79 & 0.84 \\
\hline Salt & 0.20 & 0.30 \\
\hline L-Lysine-HCl (78\%) & 0.27 & 0.13 \\
\hline Methionine & 0.10 & 0.05 \\
\hline Threonine & 0.10 & 0.04 \\
\hline Tryptophan & 0.04 & 0.01 \\
\hline Chromic oxide & 0.25 & 0.25 \\
\hline $\mathrm{ZnO}$ & 0.35 & - \\
\hline Mineral and vitamin premix ${ }^{1}$ & 0.50 & 0.50 \\
\hline \multicolumn{3}{|l|}{ Nutrient levels ${ }^{2}$} \\
\hline Digestible energy (kcal/kg) & 3,400 & 3,400 \\
\hline Dry matter & 92.65 & 91.82 \\
\hline Crude protein & 20.05 & 19.86 \\
\hline Calcium & 0.80 & 0.70 \\
\hline Phosphorus & 0.65 & 0.60 \\
\hline Available phosphorus & 0.50 & 0.38 \\
\hline Lysine & 1.40 & 1.18 \\
\hline Digestible lysine & 1.27 & 1.01 \\
\hline Methionine & 0.41 & 0.35 \\
\hline Digestible methionine & 0.38 & 0.30 \\
\hline NDF & 10.43 & 11.48 \\
\hline $\mathrm{ADF}$ & 4.16 & 4.34 \\
\hline
\end{tabular}

${ }^{1}$ Premix provided the following per $\mathrm{kg}$ of complete diet for growing pigs: vitamin A, 9,000 IU; vitamin $\mathrm{D}_{3}$, 3,000 IU; vitamin E, 64 IU; vitamin $\mathrm{K}_{3}$, $3 \mathrm{mg}$; vitamin $\mathrm{B}_{12}, 12 \mu \mathrm{g}$; riboflavin, $5.5 \mathrm{mg}$; pantothenic acid, $15 \mathrm{mg}$; niacin, $40 \mathrm{mg}$; choline chloride, $551 \mathrm{mg}$; folacin, $0.8 \mathrm{mg}$; vitamin $\mathrm{B}_{1}, 1.5$ $\mathrm{mg}$; vitamin $\mathrm{B}_{6}, 3 \mathrm{mg}$; biotin, $100 \mu \mathrm{g}$; Mn, $40 \mathrm{mg}$; Fe, $100 \mathrm{mg}$; Zn, 100 $\mathrm{mg} ; \mathrm{Cu}, 150 \mathrm{mg}$; I, $0.3 \mathrm{mg} ; \mathrm{Se}, 0.3 \mathrm{mg}$.

${ }^{2}$ Nutrient levels were calculated values.

The pigs were housed in pens of $1.2 \times 2 \mathrm{~m}^{2}$ with half cement floor and half woven mesh floor. All pigs had free access to feed and water throughout the 28-d experiment. The temperature of the pig barn was controlled between 23 and $32^{\circ} \mathrm{C}$. Pigs and feeds were weighed at d 0,7 and 28 of the experiment in order to calculate weight gain, feed intake and gain:feed ratio. Fresh fecal grab samples were collected on d 26 to 28 and pooled by pen. Approximately $100 \mathrm{~g}$ of fresh feces were collected directly from the floor of each pen into sterile plastic bags and immediately stored at $-20^{\circ} \mathrm{C}$ until chemical analysis. 
At the end of the experiment, six pigs close to average group body weight were chosen from the control group and the group supplemented with $150 \mathrm{ppm}$ enzyme complex. These 12 pigs were fasted for $24 \mathrm{~h}$. Pigs were subsequently killed after they had free access to feed for two hours. The abdomen was immediately opened and the entire gastrointestinal tract was tied to collect digesta in the different parts of the tract (stomach, small intestine, cecum and colon). The $\mathrm{pH}$ of the digesta in the stomach, ileum and cecum was measured with a Temperature-Corrected $\mathrm{pH}$ Meter (HI8424 pH meter, Hanna Instruments, China). The fresh digesta taken from the stomach, ileum and cecum was immediately refrigerated on ice and then centrifuged at $4,000 \times \mathrm{g}$ for $10 \mathrm{~min}$ at $10^{\circ} \mathrm{C}$. The supernatant was then used to determine viscosity using a Physica MCR 301 (HPTD200, Anton Paar, Graz).

Exp. 2. Apparent ileal digestibility: In Exp. 2, six crossbred barrows (Duroc $\times$ Landrace $\times$ Large White) with an average body weight of $18.06 \pm 1.2 \mathrm{~kg}$ were surgically fitted with a simple T-cannula at the distal ileum according to the methods described by Stein et al. (1998). After the surgery, the pigs were housed in adjustable, $1.2 \times 0.7 \times 0.96 \mathrm{~m}^{3}$ metabolic crates with perforated floors that allowed for freedom of movement. The pigs were fed increasing amounts of commercial diet twice daily and had unlimited access to water. After a 12-d recovery period, pigs were randomly assigned to one of three treatments according to a replicated $3 \times 3$ Latin square design.

Each experimental period lasted $7 \mathrm{~d}$, consisting of $5 \mathrm{~d}$ for acclimation to the experimental diets and $2 \mathrm{~d}$ collection of ileal digesta. The daily feed allowance was divided into two equal portions and was fed at 08:00 and 16:30 h every day. Ileal digesta were collected continuously for $12 \mathrm{~h}$ from 08:00 to 20:00 h on d 6 and 7 (Stein et al., 1998). A plastic bag was attached to the cannula using a cable tie to collect the digesta flowing into the bag. Bags were changed every $20 \mathrm{~min}$. Ileal digesta were stored on ice during the $12 \mathrm{~h}$ collection period. After each day's collection, digesta were stored at $-20^{\circ} \mathrm{C}$ to prevent bacterial degradation of the amino acids in the digesta. Digesta were lyophilized and a sub-sample was collected for analysis.

\section{Chemical analysis}

Chemical analysis of feed, feces and digesta: Feed samples were collected at the beginning of each experiment. Fecal samples in Exp. 1 were thawed, heat dried $\left(65^{\circ} \mathrm{C}, 72\right.$ h) in an oven and ground to pass through a 1-mm sieve. Digesta samples in Exp. 2 were freeze dried using a Virtis Genesis Wizzard 2.0 Freeze Dryer (SP industries, Warminster).

In Exp. 1, feed and fecal samples were analyzed for dry matter (AOAC method 930.15, 2000), crude protein (AOAC method 988.05, 2000) and calcium (AOAC method
965.17, 2000). Phosphorus content was analyzed using an UV-visible spectrophotometer (Hitachi, U-1,000 Tokyo, Japan). Gross energy was determined by an Automatic Adiabatic Oxygen Bomb Calorimeter (Parr 1281 Automatic Energy Analyzer, Moline, IL). NDF and ADF were determined using fibre bags and Fibre Analyzer (Ankom Technology, Macedon, NY) following an adaptation of the procedure described by Van Soest et al. (1991). The concentration of NDF was analyzed using heat stable $\alpha$ amylase and sodium sulphite without correction for insoluble ash. The ADF fraction was analyzed in a separate sample. The content of chromium was determined by an Automatic Absorption Spectrophotometer (Hitachi Z-5000 Automatic Absorption Spectrophotometer, Tokyo, Japan) according to Williams et al. (1962). Total starch was determined according to the method described by Thivend et al. (1972).

In Exp. 2, The amino acid content of the feed samples and digesta was assayed using ion-exchange chromatography with an Automatic Amino Acid Analyzer (L-8800 Hitachi Automatic Amino Acid Analyzer, Tokyo, Japan) after hydrolyzing with $6 \mathrm{~N} \mathrm{HCl}$ at $110^{\circ} \mathrm{C}$ for $24 \mathrm{~h}$. Cystine was determined as cysteic acid and methionine as methionine sulfone after preoxidation with performic acid and pre-column derivation using phenylisothiocyanate (L-8800 Hitachi Automatic Amino Acid Analyzer, Tokyo, Japan). Tryptophan was determined after hydrolyzing with $4 \mathrm{M} \mathrm{NaOH}$ at $110^{\circ} \mathrm{C}$ for $22 \mathrm{~h}$ using phenylisothiocyanate (Model 76337, Agilent Technologics, Waldbronn, Germany).

Enzyme activity: Sterile cell scrapers were used to obtain the jejunal and ileal mucosa ( 1 to $2 \mathrm{~g}$ and stored in capped tubes), which were placed in liquid $\mathrm{N}$ and stored at $80^{\circ} \mathrm{C}$ until needed for analysis of sucrase and maltase activities. Determination of sucrase and maltase activities of jejunal and ileal mucosa was performed using the corresponding reagent kits (Jiancheng Bioengineering Institute, Nanjing, China). One sucrase unit is defined as the quantity of enzyme required to hydrolyze $1 \mathrm{nmol}$ of sucrose per mg protein minute, at $\mathrm{pH} 5.5$ and $37^{\circ} \mathrm{C}$; Maltase was similarly defined using maltose.

Volatile fatty acid analysis: Samples of digesta from the cecum and colon of individual pigs were taken for the analysis of volatile fatty acids. Volatile fatty acid concentrations in the digesta were determined using a modified method of Porter and Murray (2001). A $1 \mathrm{~g}$ sample was diluted with $2 \mathrm{ml}$ of $0.1 \% \mathrm{HCl}$ solution and put on ice for $30 \mathrm{~min}$ and then centrifuged at $12,000 \times \mathrm{g}$ at $0^{\circ} \mathrm{C}$ for $15 \mathrm{~min}$. Exactly $1 \mathrm{ml}$ of the supernatant was passed through a $0.22 \mu \mathrm{m}$ Nylon Membrane Filter (Millipore, Bedford, $\mathrm{OH}$ ) and then $5 \mu \mathrm{l}$ of the solution was injected into a Gas Chromatographic System (Agilent HP 6890 Series, Santa Clara, CA).

Microbiology analysis: The cecal and colonic contents 
Table 2. Effect of enzyme supplementation on performance of weaned pigs ${ }^{1}$

\begin{tabular}{|c|c|c|c|c|c|c|c|}
\hline & \multicolumn{3}{|c|}{ Enzyme $^{2}$} & \multirow{2}{*}{ SEM $^{3}$} & \multicolumn{3}{|c|}{$\mathrm{p}$-value } \\
\hline & 0 & 100 & 150 & & Treatment & Linear & Quadratic \\
\hline \multicolumn{8}{|c|}{ Weight gain $(\mathrm{g} / \mathrm{d})$} \\
\hline $\mathrm{d} 1$ to 7 & $188^{\mathrm{a}}$ & $208^{\mathrm{ab}}$ & $219^{\mathrm{b}}$ & 9.28 & 0.09 & 0.03 & 0.66 \\
\hline d 8 to 28 & $416^{\mathrm{a}}$ & $466^{\mathrm{b}}$ & $479^{\mathrm{b}}$ & 10.63 & $<0.01$ & $<0.01$ & 0.18 \\
\hline d 1 to 28 & $359^{\mathrm{a}}$ & $401^{\mathrm{b}}$ & $414^{\mathrm{b}}$ & 9.13 & $<0.01$ & $<0.01$ & 0.20 \\
\hline \multicolumn{8}{|c|}{ Feed intake $(\mathrm{g} / \mathrm{d})$} \\
\hline d 1 to 7 & 260 & 262 & 274 & 8.81 & 0.50 & 0.29 & 0.62 \\
\hline d 8 to 28 & 716 & 737 & 730 & 15.90 & 0.64 & 0.93 & 0.81 \\
\hline d 1 to 28 & 602 & 618 & 616 & 12.93 & 0.65 & 0.52 & 0.62 \\
\hline \multicolumn{8}{|c|}{ Gain:feed ratio } \\
\hline $\mathrm{d} 1$ to 7 & 0.72 & 0.79 & 0.80 & 0.03 & 0.08 & 0.04 & 0.34 \\
\hline d 8 to 28 & $0.57^{\mathrm{b}}$ & $0.63^{\mathrm{a}}$ & $0.66^{\mathrm{a}}$ & 0.01 & $<0.01$ & $<0.01$ & 0.07 \\
\hline d 1 to 28 & $0.60^{\mathrm{b}}$ & $0.65^{\mathrm{a}}$ & $0.67^{\mathrm{a}}$ & 0.01 & $<0.01$ & $<0.01$ & 0.24 \\
\hline
\end{tabular}

${ }^{\mathrm{ab}}$ Means in the same row with different superscripts differ $(\mathrm{p}<0.05)$.

${ }^{1}$ Data represents mean of six pens with six pigs per pen. ${ }^{2}$ Enzyme contained 2,000 U/g of amylase, 40,000 U/g of protease and 20,000 U/g xylanase.

${ }^{3} \mathrm{SEM}=$ Standard error of the means.

were immediately placed in sterile $50 \mathrm{ml}$ capped tubes and being $\mathrm{p}<0.10$. stored on ice until laboratory analysis was conducted within $12 \mathrm{~h}$. A modification of the method as described by Orban et al. (1997) was used to determine the populations of Lactobacilli and E. coli. Cecal and colonic contents (1 g) were serially diluted $1: 9$ in sterile resazurin solution $\left(\mathrm{KH}_{2} \mathrm{PO}_{4} 0.3 \mathrm{~mol} / \mathrm{L}, \mathrm{NaOH} 0.22 \mathrm{~mol} / \mathrm{L}\right.$ and resazurin 4.3 $\mathrm{mmol} / \mathrm{L})$. Appropriate serial dilutions were used to enumerate the two bacteria $\left(10^{-5}, 10^{-6}, 10^{-7}\right.$ for Lactobacilli and $10^{-2}, 10^{-3}, 10^{-4}$ for E. coli). E. coli (Mac Conkey agar) was incubated aerobically at $37^{\circ} \mathrm{C}$ for 12 to $18 \mathrm{~h}$. Lactobacilli (MRS agar) was incubated anaerobically at $37^{\circ} \mathrm{C}$ for 12 to $18 \mathrm{~h}$. The microbial enumerations of digesta are expressed as $\log _{10}$ Colony-Forming Units per gram.

\section{Statistical analysis}

All data were processed using SAS (SAS Institute, Cary, NC) and statistically analyzed by ANOVA as a complete block design with pen in Exp. 1 and individual pig as a block in Exp. 2. Control statement in GLM model was applied to determine linear and quadratic effects of enzyme concentrations. Statistical differences among treatments were determined by the Student-Newman-Keuls Multiple Range Test. Significance was taken at $\mathrm{p}<0.05$ with a trend

\section{RESULTS}

\section{Performance and nutrient digestibility}

The performance of the pigs in Exp. 1 is presented in Table 2. During the first phase, pigs fed diets supplemented with enzyme complex at $150 \mathrm{ppm}$ tended to increase weight gain $(\mathrm{p}=0.09)$ and gain:feed ratio $(\mathrm{p}=0.08)$ compared with pigs fed the control diet. There were linear increases $(\mathrm{p}<0.01)$ in weight gain and gain:feed ratio with increasing dose rate of enzyme supplementation during phase 2 and the whole experimental period. There were no differences for feed intake $(p>0.05)$ between the treatments.

There was a linear increase in digestibility of gross energy $(p<0.01)$ with the increasing dose rate of enzyme supplementation. Pigs fed diets supplemented with enzyme complex tended to have increased digestibility of crude protein $(p=0.07)$ and dry matter $(p=0.09)$ (Table 3). However, the digestibility of starch $(p>0.05)$ was not affected by enzyme supplementation.

\section{Volatile fatty acid}

Table 4 shows the effects of enzyme supplementation on

Table 3. Effect of enzyme supplementation on nutrient digestibility (\%) of weaned pigs ${ }^{1}$

\begin{tabular}{|c|c|c|c|c|c|c|c|}
\hline & \multicolumn{3}{|c|}{ Enzyme $^{2}(\mathrm{ppm})$} & \multirow{2}{*}{$\mathrm{SEM}^{3}$} & \multicolumn{3}{|c|}{ p-value } \\
\hline & 0 & 100 & 150 & & Treatment & Linear & Quadratic \\
\hline Dry matter & 85.82 & 86.92 & 87.44 & 0.38 & 0.09 & 0.01 & 0.54 \\
\hline Energy & $84.45^{\mathrm{a}}$ & $85.89^{\mathrm{b}}$ & $86.26^{\mathrm{b}}$ & 0.40 & 0.05 & $<0.01$ & 0.29 \\
\hline Crude protein & 79.51 & 81.93 & 82.30 & 0.74 & 0.07 & 0.02 & 0.27 \\
\hline Starch & 99.49 & 99.51 & 99.56 & 0.06 & 0.62 & 0.42 & 0.79 \\
\hline
\end{tabular}

${ }^{\mathrm{ab}}$ Means in the same row with different superscripts differ $(\mathrm{p}<0.05)$

${ }^{1}$ Data represents mean of six pens with six pigs per pen. ${ }^{2}$ Enzyme contained 2,000 U/g of amylase, 40,000 U/g of protease and 20,000 U/g xylanase.

${ }^{3} \mathrm{SEM}=$ Standard error of the means. 
Table 4. Effect of enzyme supplementation on volatile fatty acid concentrations (mg/g of digesta) in the cecum and colon of weaned pigs ${ }^{1}$

\begin{tabular}{lcccc}
\hline & \multicolumn{2}{c}{ Enzyme $^{2}(\mathrm{ppm})$} & \multirow{2}{*}{ SEM $^{3}$} & p-value \\
\cline { 2 - 3 } & 0 & 150 & & \\
\hline Cecum & & & & \\
$\quad$ Acetic acid & 4.21 & 6.81 & 0.17 & $<0.01$ \\
$\quad$ Propionic acid & 2.11 & 2.87 & 0.12 & 0.01 \\
$\quad$ Butyric acid & 0.85 & 1.35 & 0.08 & 0.01 \\
Colon & & & & \\
$\quad$ Acetic acid & 3.20 & 5.48 & 0.20 & $<0.01$ \\
$\quad$ Propionic acid & 1.36 & 2.34 & 0.06 & $<0.01$ \\
$\quad$ Butyric acid & 0.74 & 1.20 & 0.05 & $<0.01$ \\
\hline ab Means in the same row with different superscripts differ (p<0.05). \\
${ }^{1}$ Data represents mean of six pens with six pigs per treatment. \\
${ }^{2}$ Enzyme contained 2,000 U/g of amylase, 40,000 U/g of protease and \\
20,000 U/g xylanase. \\
${ }^{3}$ SEM =Standard error of the means.
\end{tabular}

cecal and colonic volatile fatty acid concentrations. Supplementation with enzyme complex significantly increased $(p<0.01)$ the concentrations of acetic, propionic and butyric acids in both the cecum and colon compared with pigs fed the control diet.

\section{Microbial counts in large intestine}

The effect of enzyme supplementation on cecal and colonic microbiota is presented in Table 5. Enzyme supplementation significantly increased the population of Lactobacilli $(\mathrm{p}<0.01)$ in the cecum. In the colon, the population of $E$. coli $(\mathrm{p}<0.05)$ was lower for pigs fed the diets supplemented with enzyme than those without enzyme supplementation.
Table 5. Effect of enzyme supplementation on large intestinal microbiota in the cecum and colon of weaned pigs ${ }^{1,2}$

\begin{tabular}{lcccc}
\hline & \multicolumn{2}{c}{ Enzyme $^{3}(\mathrm{ppm})$} & \multirow{2}{*}{ SEM $^{4}$} & p-value \\
\cline { 2 - 3 } & 0 & 150 & & \\
\hline Cecum & & & & \\
$\quad$ E. coli & 7.06 & 6.51 & 0.17 & 0.18 \\
$\quad$ Lactobacilli & 7.86 & 8.33 & 0.05 & $<0.01$ \\
Colon & & & & \\
$\quad$ E. coli & 8.05 & 7.25 & 0.13 & 0.02 \\
$\quad$ Lactobacilli & 8.33 & 8.84 & 0.11 & 0.06 \\
\hline
\end{tabular}

${ }^{\mathrm{ab}}$ Means in the same row with different superscripts differ $(\mathrm{p}<0.05)$

${ }^{1}$ Data represents mean of six pens with six pigs per treatment.

${ }^{2}$ Bacterial numbers are expressed as $\log _{10}$ colony forming units per gram.

${ }^{3}$ Enzyme contained 2,000 U/g of amylase, 40,000 U/g of protease and $20,000 \mathrm{U} / \mathrm{g}$ xylanase.

${ }^{4} \mathrm{SEM}=$ Standard error of the means.

\section{Digesta viscosity, $\mathrm{pH}$ and mucosa enzymatic activity}

Viscosities of digestive contents in the stomach $(p<0.05)$ were greater for pigs fed the diet supplemented with enzyme but no differences ( $p>0.05)$ were observed in the ileam and cecum. Supplementing the diet with the enzyme tended to decrease the $\mathrm{pH}$ in the cecum $(\mathrm{p}<0.05)$, but there was no differences $(p>0.05)$ in the $\mathrm{pH}$ of the stomach or ileam (Table 6).

\section{Apparent ileal digestibility of amino acids}

The pigs recovered well from the surgery and remained healthy during the entire experiment. The apparent ileal digestibility of amino acids is presented in Table 7. Enzyme supplementation linearly increased the apparent ileal

Table 6. Effects of enzyme supplementation on digesa viscosity, $\mathrm{pH}$ and jejunal and ileal mucosa enzymatic activity of weaned pigs ${ }^{1}$

\begin{tabular}{|c|c|c|c|c|}
\hline & \multicolumn{2}{|c|}{ Enzyme $^{2}(\mathrm{ppm})$} & \multirow{2}{*}{$\mathrm{SEM}^{3}$} & \multirow{2}{*}{ p-value } \\
\hline & 0 & 150 & & \\
\hline \multicolumn{5}{|l|}{ Digesta $\mathrm{Ph}$} \\
\hline Stomach & 3.46 & 3.27 & 0.75 & 0.43 \\
\hline Ileum & 6.13 & 5.45 & 0.65 & 0.37 \\
\hline Cecum & 5.76 & 5.35 & 0.10 & 0.08 \\
\hline \multicolumn{5}{|c|}{ Digesta viscosity (mPa·s) } \\
\hline Stomach & 0.92 & 1.34 & 0.08 & 0.03 \\
\hline Ileum & 1.06 & 1.12 & 0.03 & 0.18 \\
\hline Cecum & 2.82 & 3.21 & 0.13 & 0.06 \\
\hline \multicolumn{5}{|c|}{ Enzyme activity, jejunal mucosa (U/mg of protein) } \\
\hline Sucrase & 18.05 & 19.49 & 1.97 & 0.84 \\
\hline Maltase & 122.84 & 161.5 & 22.73 & 0.51 \\
\hline \multicolumn{5}{|c|}{ Enzyme activity, ileal mucosa (U/mg of protein) } \\
\hline Sucrase & 34.18 & 38.19 & 3.65 & 0.65 \\
\hline Maltase & 175.24 & 217.32 & 36.95 & 0.84 \\
\hline
\end{tabular}

${ }^{\mathrm{ab}}$ Means in the same row with different superscripts differ $(\mathrm{p}<0.05)$.

${ }^{1}$ Data represents mean of six pens with six pigs per treatment.

${ }^{2}$ Enzyme contained 2,000 U/g of amylase, 40,000 U/g of protease and 20,000 U/g xylanase. ${ }^{3} \mathrm{SEM}=\mathrm{Standard}$ error of the means. 
Table 7. Effects of enzyme supplementation on apparent ileal digestibility of amino acids of weaned pigs ${ }^{1}$

\begin{tabular}{|c|c|c|c|c|c|c|c|}
\hline & \multicolumn{3}{|c|}{ Enzyme $^{2}$} & \multirow{2}{*}{ SEM $^{3}$} & \multicolumn{3}{|c|}{ p-value } \\
\hline & 0 & 100 & 150 & & Treatment & Linear & Quadratic \\
\hline Crude protein & 74.15 & 80.57 & 81.95 & 3.25 & 0.08 & 0.04 & 0.33 \\
\hline \multicolumn{8}{|c|}{ Indispensable amino acids } \\
\hline Arginine & 83.27 & 86.53 & 88.59 & 1.82 & 0.06 & 0.02 & 0.66 \\
\hline Phenylalanine & 81.82 & 84.30 & 85.66 & 2.10 & 0.21 & 0.09 & 0.73 \\
\hline Histidine & 81.01 & 83.33 & 84.72 & 1.90 & 0.17 & 0.07 & 0.75 \\
\hline Isoleucine & $80.21^{\mathrm{a}}$ & $86.09^{\mathrm{b}}$ & $86.19^{\mathrm{b}}$ & 1.59 & 0.02 & $<0.01$ & 0.06 \\
\hline Leucine & 82.54 & 83.25 & 86.53 & 1.56 & 0.07 & 0.04 & 0.31 \\
\hline Lysine & 82.61 & 88.99 & 89.22 & 2.82 & 0.08 & 0.05 & 0.20 \\
\hline Methionine & 83.97 & 85.56 & 86.48 & 3.01 & 0.35 & 0.37 & 0.88 \\
\hline Threonine & 78.69 & 81.85 & 83.08 & 2.82 & 0.26 & 0.13 & 0.65 \\
\hline Valine & $79.79^{\mathrm{a}}$ & $82.90^{\mathrm{b}}$ & $82.99 b$ & 0.86 & 0.02 & 0.01 & 0.07 \\
\hline Tryptophan & 78.23 & 82.52 & 85.42 & 2.99 & 0.10 & 0.04 & 0.76 \\
\hline \multicolumn{8}{|c|}{ Dispensable amino acids } \\
\hline Alanine & 76.62 & 79.94 & 81.60 & 3.75 & 0.35 & 0.18 & 0.77 \\
\hline Aspartic acid & $79.22^{\mathrm{a}}$ & $82.59^{\mathrm{b}}$ & $82.67^{\mathrm{b}}$ & 1.16 & 0.04 & 0.02 & 0.12 \\
\hline Glutamic acid & 89.07 & 89.79 & 90.28 & 1.33 & 0.58 & 0.33 & 0.91 \\
\hline Cystine & 68.67 & 71.82 & 73.10 & 3.19 & 0.32 & 0.16 & 0.70 \\
\hline Glycine & 69.35 & 73.36 & 74.76 & 2.87 & 0.17 & 0.08 & 0.56 \\
\hline Proline & 83.41 & 85.46 & 86.20 & 3.19 & 0.58 & 0.34 & 0.79 \\
\hline Serine & 78.48 & 81.81 & 84.11 & 3.59 & 0.18 & 0.13 & 0.85 \\
\hline Tyrosine & 87.68 & 88.51 & 89.45 & 3.24 & 0.45 & 0.54 & 0.98 \\
\hline
\end{tabular}

${ }^{\mathrm{ab}}$ Means in the same row with different superscripts differ $(\mathrm{p}<0.05)$.

${ }^{1}$ Value represents mean of six pigs. ${ }^{2}$ Enzyme contained 2,000 U/g of amylase, 40,000 U/g of protease and 20,000 U/g xylanase.

${ }^{3} \mathrm{SEM}=$ Standard error of the means.

digestibility of isoleucine $(p<0.01)$, valine $(p<0.05)$, aspartic acid $(\mathrm{p}<0.05)$, and tended to increase the apparent ileal digestibility of crude protein $(\mathrm{p}=0.08)$, arginine $(\mathrm{p}=$ $0.06)$, leucine $(p=0.07)$, and lysine $(p=0.08)$. The digestibility of most amino acids was numerically increased by enzyme supplementation.

\section{DISCUSSION}

Adding the enzyme blend to piglet diet improved body weight gain and gain:feed ratio over 8 to $12 \%$ in the current experiment. This result is consistent with previous reports (Pettey et al., 2002; Fang et al., 2007; Ji et al., 2008). Kim et al. (2003) reported that supplementing carbohydrase in corn-soybean based-diets to nursery pigs improved gain:feed ratio by 7 to $9 \%$. The greater improvement ( 8 to $12 \%$ ) in gain:feed ratio obtained in this study may be due to the different enzyme profiles used. In this study, enzyme complex contained xylanase, amylase and protease with targeted substrates including NSP, indigestible starch and protein. While in the experiment of Kim et al. (2003), the enzyme used contained $\beta$-1,4-mannanase, $\beta$-1,4mannosidase and $\alpha-1,6$-galactosidase, which only targeting on NSPs.

Enzyme supplementation improved the digestibility of gross energy, crude protein, and dry matter by 2,4 and $2 \%$, respectively in Exp. 1. This result is consistent with previous findings (Caine et al., 1998; Café et al., 2002; Olukosi et al., 2007). For example, Caine et al. (1998) reported that supplementation of protease can increase the solubility of soybean protein and decrease the effect of trypsin inhibitors. The use of carbohydrases in cornsoybean based-diets improved ileal energy digestibility for grower-finisher pigs (Kim et al., 2006). The improvement in nutrient digestibility in our study indicates that the enzyme complex may have exerted its beneficial effects on nutrient digestibility, and thus performance, through first breaking down the plant cell wall structure and then releasing the nutrients contained in the cell wall for use by the pig (Bedford and Schulze, 1998).

Sucrase and maltase are intestinal brush border glycoside hydrolases and are responsible for the final steps of carbohydrate digestion. Hedemann et al. (2006) reported that pigs fed high insoluble fiber diets had increased mucosal enzyme activity. This suggests that the activity of these enzymes at the ileal brush border may be modulated by the amount of fermentable material reaching the hindgut. However, in the current study, no differences in activity of these enzymes were found among treatments on the jejunal and ileal brush border enzyme activities. Similarly, there was no difference on the jejunal and ileal brush border enzyme activities for pigs fed diets supplemented with or 
without enzymes (Li et al., 2004; Willamil et al., 2012). Brush border enzyme activities may depend on several factors such as the section of small intestine (Hedemann et al., 2006) and pig age (Fan et al., 2002). These factors might help to explain the differences among studies.

In our study, the viscosity of the digesta in the stomach was higher for pigs fed the diet supplemented with enzyme complex than for pigs fed the diet without enzyme complex. The reason for the increase in digesta viscosity in stomach may be that enzyme supplementation degraded the insoluble NSPs fraction into short-chain polymers with increased solubility and water holding capacity of the digesta. An increase in digesta viscosity for a diet supplemented with enzyme was also observed by Li et al. (2004) and Willamil et al. (2012).

Bach Knudsen et al. (1991), Teitelbaum and Walker (2002), and Wong et al. (2006) demonstrated that soluble NSPs contained in the diet helped to stimulate the growth of commensal gut flora and thus increased the production of short-chain fatty acids, reduced $\mathrm{pH}$ in the large intestine and inhibited potentially harmful bacteria. In our study, the cecal and colonic volatile fatty acid concentrations were significantly higher for pigs fed the diet supplemented with enzyme complex than for those without enzymes. Högberg and Lindberg (2004) also showed similar results, where enzyme supplementation markedly increased volatile fatty acid concentrations and lowered the $\mathrm{pH}$ in the cecum. The increase of volatile fatty acids in the cecum and colon may have some beneficial effects. Wong et al. (2006) reported that butyrate is of great interest for it is a preferred energy source for colonocytes (Roediger, 1982); it also stimulates colon epithelial cells thus increasing the absorptive capacity of the epithelium (Topping and Clifton, 2001). This may further explain the better performance observed for pigs fed diets supplemented with enzyme complex in our study.

This study further demonstrated that adding enzymes to the piglet diets can improve apparent ileal digestibility of amino acid. Barrera et al. (2004) also reported that supplementing xylanase improved ileal digestibility of some amino acids in wheat-based diet of growing pigs. Yin et al. (2001a) and Yin et al. (2001b) reported that the inclusion of xylanase in diets containing hulless barley increased apparent ileal digestibility of some amino acids. Dierick and Decuypere (1994) suggested that xylanase supplementation could break down cell wall, eliminating the encapsulating effects of the cell wall and thus increased the digestion of protein at the proximal of the small intestine.

\section{IMPLICATIONS}

The results of the present study clearly demonstrate that the supplementation of an enzyme complex containing amylase, protease and xylanase improved performance in young pigs. This improvement was likely mediated through changes in nutrient digestibility, volatile fatty acid concentrations and bacteria in the large intestine.

\section{REFERENCES}

AOAC. 2000. Official methods of analysis. 17th ed. Association of Official Analytical Chemists, Arlington, VA.

Barrera, M., M. Cervantes, W. Sauer, A. Araiza, and N. Torrentera. 2004. Ileal amino acid digestibility and performance of growing pigs fed wheat-based diets supplemented with xylanase. J. Anim. Sci. 82:1997-2003.

Bedford, M., and H. Schulze. 1998. Exogenous enzymes for pigs and poultry. Nutr. Res. Rev. 11:91-114

Cadogan, D., M. Choct, and R. Campbell. 2003. Effects of storage time and exogenous xylanase supplementation of new season wheats on the performance of young male pigs. Can. J. Anim. Sci. 83:105-112.

Café, M., C. Borges, C. Fritts, and P. Waldroup. 2002. Avizyme improves performance of broilers fed corn-soybean mealbased diets. J. Appl. Poult. Res. 11:29-33.

Caine, W., M. Verstegen, W. Sauer, S. Tamminga, and H. Schulze. 1998. Effect of protease treatment of soybean meal on content of total soluble matter and crude protein and level of soybean trypsin inhibitors. Anim. Feed Sci. Technol. 71:177-183.

Dierick, N., and J. Decuypere. 1994. Enzymes and growth in pigs. In: Principles of Pig Science (Ed. D. Cole, J. Wiseman and M. Varley), Nottingham University Press, p. 168.

Fan, M. Z., O. Adeola, E. K. Asem, and D. King. 2002. Postnatal ontogeny of kinetics of porcine jejunal brush border membrane-bound alkaline phosphatase, aminopeptidase $\mathrm{N}$ and sucrase activities. Comp. Biochem. Physiol. Part A. Mol. Integr. Physiol. 132:599-607.

Fang, Z., J. Peng, Z. Liu, and Y. Liu. 2007. Responses of nonstarch polysaccharide-degrading enzymes on digestibility and performance of growing pigs fed a diet based on corn, soya bean meal and Chinese double-low rapeseed meal. J. Anim. Physiol. Anim. Nutr. 91:361-368.

Francesch, M., and P. Geraert. 2009. Enzyme complex containing carbohydrases and phytase improves growth performance and bone mineralization of broilers fed reduced nutrient cornsoybean-based diets. Poult. Sci. 88:1915-1924.

Hedemann, M. S., M. Eskildsen, H. N. Lærke, C. Pedersen, J. Lindberg, P. Laurinen, and K. E. Bach Knudsen. 2006. Intestinal morphology and enzymatic activity in newly weaned pigs fed contrasting fiber concentrations and fiber properties. J. Anim. Sci. 84:1375-1386.

Högberg, A., and J. E. Lindberg. 2004. Influence of cereal nonstarch polysaccharides and enzyme supplementation on digestion site and gut environment in weaned piglets. Anim. Feed Sci. Technol. 116:113-128.

Ji, F., D. Casper, P. Brown, D. Spangler, K. Haydon, and J. Pettigrew. 2008. Effects of dietary supplementation of an enzyme blend on the ileal and fecal digestibility of nutrients in growing pigs. J. Anim. Sci. 86:1533-1543.

Kim, S., D. Knabe, K. Hong, and R. Easter. 2003. Use of carbohydrases in corn-soybean meal-based nursery diets. J. 
Anim. Sci. 81:2496-2504.

Kim, S., H. Jin, T. Kevin, and A. Darrell. 2006. Use of carbohydrases in corn-soybean meal based grower-finisher pig diets. Anim. Res. 55:563-578.

Bach Knudsen, K. E. 1997. Carbohydrate and lignin contents of plant materials used in animal feeding. Anim. Feed Sci. Technol. 67:319-338.

Bach Knudsen, K. E.., B. Jensen, and J. Andersen. 1991. Gastrointestinal implications in pigs of wheat and oat fractions. Br. J. Nutr. 65:233-248.

Li, W. F., J. Feng, Z. R. Xu, and C. M. Yang. 2004. Effects of nonstarch polysaccharides enzymes on pancreatic and small intestinal digestive enzyme activities in piglet fed diets containing high amounts of barley. World J. Gastroenterol. 10:856-859.

Mavromichalis, I., J. Hancock, B. Senne, T. Gugle, G. Kennedy, R. Hines, and C. Wyatt. 2000. Enzyme supplementation and particle size of wheat in diets for nursery and finishing pigs. J. Anim. Sci. 78:3086-3095.

NRC. 1998. Nutrient requirements of swine. 10th rev. ed. National Academy Press, Washington, DC.

Olukosi, O., M. Bedford, and O. Adeola. 2007. Xylanase in diets for growing pigs and broiler chicks. Can. J. Anim. Sci. 87:227235.

Orban, J., J. Patterson, O. Adeola, A. Sutton, and G. Richards. 1997. Growth performance and intestinal microbial populations of growing pigs fed diets containing sucrose thermal oligosaccharide caramel. J. Anim. Sci. 75:170-175.

Pettey, L., S. Carter, B. Senne, and J. A. Shriver. 2002. Effects of beta-mannanase addition to corn-soybean meal diets on growth performance, carcass traits, and nutrient digestibility of weanling and growing-finishing pigs. J. Anim. Sci. 80:10121019.

Porter, M., and R. Murray. 2001. The volatility of components of grass silage on oven drying and the inter-relationship between dry-matter content estimated by different analytical methods. Grass Forage Sci. 56:405-411

Roediger, W. 1982. Utilization of nutrients by isolated epithelial cells of the rat colon. Gastroenterology 83:424-429.

Stein, H. H., C. F. Shipley, and R. A. Easter. 1998. Technical note: A technique for inserting a T-cannula into the distal ileum of pregnant sows. J. Anim. Sci. 76:1433-1436.

Summers, J. D. 2001. Maize: Factors affecting its digestibility and variability in its feeding value. Pages 109-124 in Enzymes in Farm Animal Nutrition (Ed. M. B. G. Partridge). CABI Publishing, Wallingford, UK.

Teitelbaum, J. E., and W. A. Walker. 2002. Nutritional impact of pre-and probiotics as protective gastrointestinal organisms. Annu. Rev. Nutr. 22:107-138.

Thivend, P., C. Mercier, and A. Guilbot. 1972. Determination of starch with glucoamylase. Methods Carbohydr. Chem. 6:100105.
Topping, D. L., and P. M. Clifton. 2001. Short-chain fatty acids and human colonic function: Roles of resistant starch and nonstarch polysaccharides. Physiol. Rev. 81:1031-1064.

Van Soest, P. J., J. Robertson, and B. A. Lewis. 1991. Methods for dietary fiber, neutral detergent fiber, and non-starch polysaccharides in relation to animal nutrition. J. Dairy Sci. 74:3583-3597.

Willamil, J., I. Badiola, E. Devillard, P. Geraert, and D. Torrallardona. 2012. Wheat-barley-rye- or corn-fed growing pigs respond differently to dietary supplementation with a carbohydrase complex. J. Anim. Sci. 90:824-832.

Williams, C. D., D. J. David, and O. Iismaa. 1962. The determination of chromic oxide in faeces sample y atomic absorption spectrophotometry. J. Agric. Sci. 59:381-385.

Wong, J. M. W., R. de Souza, C. W. C. Kendall, A. Emam, and D. J. A. Jenkins. 2006. Colonic health: Fermentation and short chain fatty acids. J. Clin. Gastroenterol. 40:235-243.

Woyengo, T., J. Sands, W. Guenter, and C. Nyachoti. 2008. Nutrient digestibility and performance responses of growing pigs fed phytase-and xylanase-supplemented wheat-based diets. J. Anim. Sci. 86:848-857.

Yin, Y.-L., S. Baidoo, L. Jin, Y. Liu, H. Schulze, and P. Simmins. 2001a. The effect of different carbohydrase and protease supplementation on apparent (ileal and overall) digestibility of nutrients of five hulless barley varieties in young pigs. Livest. Prod. Sci. 71:109-120.

Yin, Y.-L., J. McEvoy, H. Schulze, U. Hennig, W.-B. Souffrant, and K. McCracken. 2000a. Apparent digestibility (ileal and overall) of nutrients and endogenous nitrogen losses in growing pigs fed wheat (var. Soissons) or its by-products without or with xylanase supplementation. Livest. Prod. Sci. 62:119-132.

Yin, Y., S. Baidoo, H. Schulze, and P. Simmins. 2001b. Effects of supplementing diets containing hulless barley varieties having different levels of non-starch polysaccharides with $\beta$-glucanase and xylanase on the physiological status of the gastrointestinal tract and nutrient digestibility of weaned pigs. Livest. Prod. Sci. 71:97-107.

Yin, Y., J. McEvoy, H. Schulze, and K. McCracken. 2000b. Studies on cannulation method and alternative indigestible markers and the effects of food enzyme supplementation in barley-based diets on ileal and overall apparent digestibility in growing pigs. Anim. Sci. 70:63-72.

Yin, Y., J. McEvoy, H. Schulze, and K. McCracken. 2001c. Effects of xylanase and antibiotic addition on ileal and overall apparent digestibility and evaluating HCL-insoluble ash as an indigestible marker in growing pigs. Anim Sci 72:95-103.

Yu, B., S. Wu, C. Liu, R. Gauthier, and P. W. S. Chiou. 2007. Effects of enzyme inclusion in a maize-soybean diet on broiler performance. Anim. Feed Sci. Technol. 134:283-294. 